\title{
Amino acid supplementation and impact on immune function in the context of exercise
}

\author{
Vinicius Fernandes Cruzat $^{1 *}$, Maurício Krause ${ }^{2}$ and Philip Newsholme ${ }^{1 *}$
}

\begin{abstract}
Moderate and chronic bouts of exercise may lead to positive metabolic, molecular, and morphological adaptations, improving health. Although exercise training stimulates the production of reactive oxygen species (ROS), their overall intracellular concentration may not reach damaging levels due to enhancement of antioxidant responses. However, inadequate exercise training (i.e., single bout of high-intensity or excessive exercise) may result in oxidative stress, muscle fatigue and muscle injury. Moreover, during the recovery period, impaired immunity has been reported, for example; excessive-inflammation and compensatory immunosuppression. Nutritional supplements, sometimes referred to as immuno-nutrients, may be required to reduce immunosuppression and excessive inflammation. Herein, we discuss the action and the possible targets of key immuno-nutrients such as L-glutamine, L-arginine, branched chain amino acids (BCAA) and whey protein.
\end{abstract}

Keywords: Immunonutrition, L-glutamine, L-arginine, L-leucine, Oxidative stress

\section{Introduction}

Elite athletes competing in national and international events are required to engage in multiple strenuous exercise training sessions to improve their performance. Although regular practice and moderate intensity exercise, for the general population, is essential to reduce the risk of chronic inflammatory diseases, athletes engaged in intense, prolonged or exhaustive physical exercise are more susceptible to the adverse effects from high-intensity exercise. Such effects include high rates of protein catabolism, a pro-inflammatory profile, accompanied by muscle damage, soreness, chronic oxidative stress [1] and immune suppression [2,3]. A large number of studies have reported the harmful side effects (overtraining syndrome) and increased upper respiratory tract infection (URTI) promoted by exhaustive physical exercise $[2,4,5]$.

Although a balanced diet with high quality and sufficient quantity of nutrients is essential, there is growing evidence that some non-synthetic supplements can assist optimal nutrition. In fact, the use of nutritional supplements especially the provision of amino acids, has grown year-on-year [6]. There are few articles in the literature

\footnotetext{
* Correspondence: vinifc@usp.br; philip.newsholme@curtin.edu.au 'CHIRI Biosciences Research Precinct, Faculty of Health Sciences, School of Biomedical Sciences, Curtin University, GPO Box U1987, Perth, Western Australia, Australia

Full list of author information is available at the end of the article
}

to address the topic of nutritional supplementation and immune consequences, from a metabolic and molecular standpoint. The use of proteins and amino acids for supplementation deserves special attention, since these molecules are critical for anti-oxidant and fuel provision, participating in the whole-body energy homeostasis, growth, development, recovery and immune responses. The key targets for immunonutrition may include provision of key metabolites for immune cells per se, the inflammatory response and cytokine release, the production of chaperone proteins such as the heat shock proteins (HSPs), redox balance (including glutathione, GSH metabolism), and protection of skeletal muscle mass (Figure 1).

\section{The evolution of immunonutrition}

Key considerations that motivate athletes to consume nutritional supplements include: i) to improve their performance, ii) to strengthen immune function and, iii) to minimise the exercise recovery period [7]. The most widely used supplements are vitamins and minerals. Many studies have described the use of proteins, such as whey for supplements or isolated amino acids [8,9]. Although the use of nutritional ergogenic aids in sports is topical, how and which nutrients may impact health and immune defense are interesting to the clinical nutrition field. 


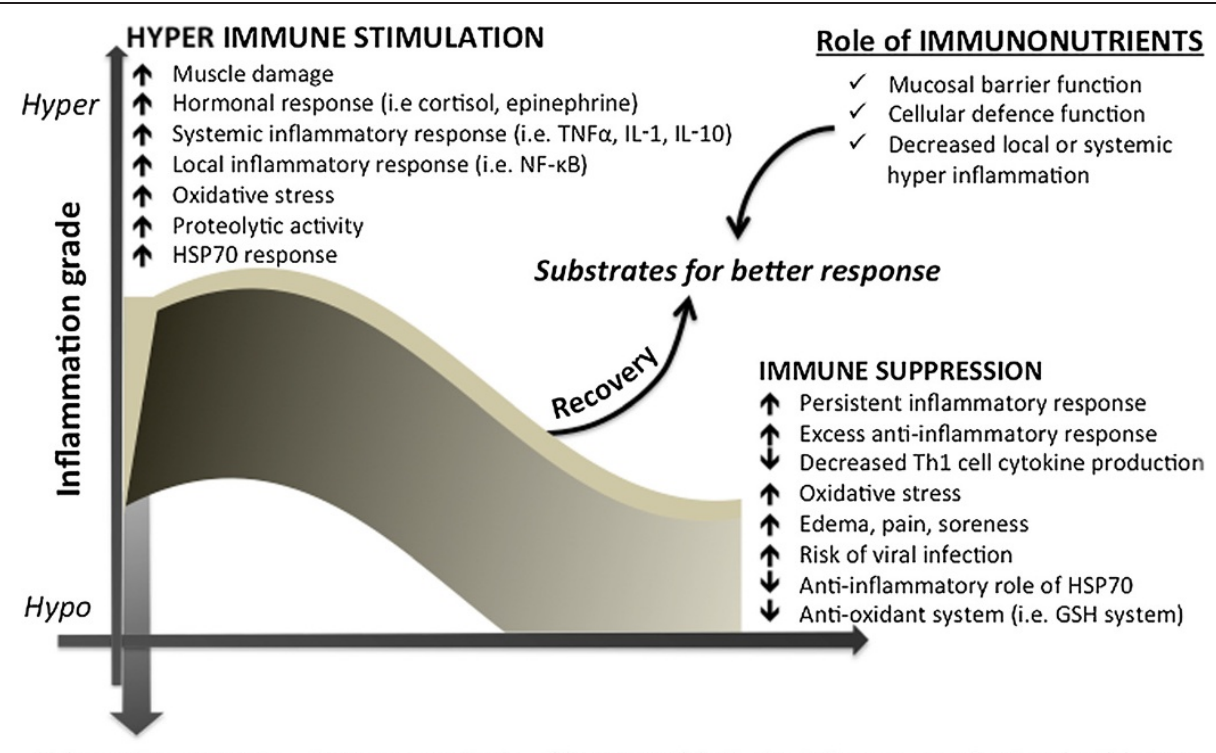

Exhaustive exercise, intense periods of heavy athletic training or overtrained athletes

Figure 1 Biphasic immuno-inflammatory response to severe exercise and the possible immunonutrition role. Immuno-inflammatory response induced by severe exercise or heavy periods of training and the proposed role of specific nutrients with immune benefits, also called immunonutrition. Abbreviations: tumor necrosis factor-alpha (TNF-a), interleukin-1 (IL-1), interleukin-10 (IL-10), nuclear Factor-kB (NF-kB), glutathione (GSH), heat shock protein $70 \mathrm{kda}(\mathrm{HSP} 70)$.

The role of nutritional support for immune function can be traced to 1810, when J. F. Menkel described that malnourished people in England presented with thymus atrophy. Other reports from the early 1900s, describe vitamin intervention studies [10] and reports exist from Ghetto physicians during World War II as to the poor health outcomes due to malnutrition [11]. More recently, positive outcomes related to total parenteral nutrition (TPN) administration, required during intensive medical care, have been described. These developments subsequently resulted in the formulation of products that could potentially modulate immune system activity, described as "immunonutrition" products. These interventions became popular for use with patients after 1990.

Most of the recent studies clearly demonstrate the importance of nutrients for trauma and surgical patients, as well as the frail elderly. Hence, strategies that include specific nutrients for enhanced immune function are frequently used in clinical nutrition therapy (e.g., for patients with burns, sepsis, cancer, HIV) and post-surgical situations using enteral or TPN routes. However, the concept of immunonutrition may be more widely applied, since the specific nutritional substrates for immune response can act on alternative targets, such as the gut mucosal barrier. Since athletes are at increased risk of upper respiratory tract infection (URTI), overtraining syndrome, chronic inflammatory response and oxidative stress [4], during and after periods of heavy exercise [12], immunonutritional approaches may be considered for future recommendations in the sport science field (Figure 1).

\section{Exercise-induced changes in the immune system: an overview \\ Changes in cytokine profile}

Regular practice of moderate-intensity physical exercise has been shown to efficiently and positively impact physiological imbalances caused by different pathological situations. Exercise has been prescribed as a complementary therapeutic strategy in different modes of immunological dysfunction [13]. It has been clearly demonstrated that exercise induces considerable changes in immune function related to physiological responses to both metabolic and hormonal exercise-related alterations (Figure 1). Most of the exercise responses on the immune system are mediated by hormones such as adrenalin, cortisol, growth hormone (GH), and pro- and anti-inflammatory cytokines. The immunological changes are dependent on exercise intensity, type, and duration. For instance, cytokine production is modulated by a range of physiological stimuli that accompany exercise, such as stress hormones, energy crisis and oxidative stress [14]. In turn, exercise-induced cytokine effects depend on the type of mediator involved and the balance between pro-inflammatory cytokines (IL-1, TNF- $\alpha$, IFN $\alpha$, IFN $\gamma$, TNF- $\beta$, IL-2, IL-12, and MCP-1) and anti-inflammatory ones (IL-4, IL-10, IL-13, IL-12p40, IL-1ra).

During moderate intensity exercise, pro-inflammatory cytokine production is downregulated and anti-inflammatory 
cytokines, such as IL-1 receptor antagonist (IL-1ra), IL-10 and IL-6, are upregulated [15-17]. Strenuous and prolonged exercise induces increases in circulating TNF- $\alpha$, IL-1 $\beta$ and IL-6 levels. This is counterbalanced by cytokine inhibitors (IL-1ra, sTNF-r1 and sTNF-r2) and the antiinflammatory cytokine IL-10 [18]. The magnitude of the changes differs markedly depending on the cytokine being examined. For instance, plasma concentrations of IL-1 and TNF- $\alpha$ increase one-to two fold, whereas IL- 6 has been reported to increase over 100-fold after prolonged exercise [18].

A large number of studies have reported increased plasma concentrations of anti-inflammatory cytokines, such as IL-1ra, IL-4 and IL-10, after various forms of exercise including brief maximal exercise [19], resistance exercise [19,20], downhill running [21,22], intense eccentric cycling [23], and endurance running and cycling $[19,24,25]$. Increased production of anti-inflammatory cytokines during exercise may serve to restrict proinflammatory reactions to exercise-induced muscle damage [23] and may also limit the production of pro-inflammatory cytokines associated with the development of ill states [26]. Conversely, increased production of anti-inflammatory cytokines during severe exercise may result in enhanced susceptibility to infections via alteration in the pro- vs. anti-inflammatory cytokine balance favoring an antiinflammatory response [25].

Importantly, exercise induces robust increases in production and release of IL-6 [27,28] from skeletal muscle. IL- 6 then stimulates the appearance, in the circulation, of the anti-inflammatory cytokines IL-1ra and IL-10, and inhibits the production of the pro-inflammatory cytokine TNF- $\alpha[18,26]$. Hence, moderate exercise may decrease pro-inflammatory cytokine production while increasing anti-inflammatory cytokine production and action, which may induce a very strong anti-inflammatory cytokine response. The main modulator of these responses is likely the appearance of IL-6 in the circulation.

Another immune-regulatory protein that is now receiving considerable attention is HSP72. Studies have demonstrated HSP72 participation in conditions associated with inflammation such as type 1 (T1DM) and type 2 diabetes mellitus (T2DM), aging, and obesity [29-32]. HSP72 can induce different inflammatory responses according to its location (intra $v s$. extracellular) positioning this protein as a master regulator for the fine-tuned control of the immune system: while iHSP70 has anti-inflammatory effects, eHSP70 induce the opposite. Physical exercise is a very well known inductor of HSP70 expression [30,33,34]. Interestingly, some studies have demonstrated that exercise is a physiological stimulus that promotes an increase in the eHSP70 concentration $[35,36]$. Both intensity and duration of exercise have effects as determined in plasma [37] and muscle samples [33,34]. The rise in circulating levels of eHSP70 precedes any gene or protein expression changes in HSP70 in skeletal muscle [27,34]. Additionally, acute exercise induces transient changes in the numbers and response of circulating lymphocytes which are considered a major eHSP70 source (nearly 100\% of total eHSP70 release from the immune system) [38,39].

\section{Muscle damage, oxidative stress and inflammation}

Activation of immune responses and adaptations after an acute exercise bout is related to muscle damage. Skeletal muscle damage that normally occurs after an acute and intense exercise bout is followed by a local inflammatory response that is "dose-dependent" on the intensity and duration of the exercise [40]. Moderate local inflammation is essential for the adaptation of the muscle, bone, and connective tissues [41]. The subsequent inflammation that occurs in response to the muscle damage is induced and intensified by the production of reactive oxygen and nitrogen species (ROS and RNS, respectively). Additionally, several cytokines (most pro-inflammatory), and molecules (histamine, serotonin and prostaglandins) are released, causing edema, pain and further inflammation until resolution and muscle recovery occurs [42-44]. Local inflammatory reactions may be induced during muscle cell apoptosis or necrosis by activated macrophages and by inflammatory cytokines [45].

The sources of ROS in exercise are many, for example, the activation of the superoxide generating NADPHoxidase from immune cells that infiltrate the damaged area [46]. Elevated metabolism or enhanced mitochondrial activity (i.e. exercise), can continuously subject many tissue specific cells to insult from ROS and RNS. Intracellular $\mathrm{O}_{2}^{-}$may combine with $\mathrm{NO}$ to generate peroxynitrite, which may cause inhibition of activity of number of key signal transducing or metabolic enzymes [1]. Overproduction of ROS or a failure in intracellular defenses against ROS may stimulate molecular events resulting in disease [1]. There is a direct relation between muscle damage, neutrophil infiltration and ROS generation during the inflammatory process [43]. The free radical production during exercise has an essential role for signal transduction, the induction of cell damage, and for the initiation of the inflammatory response. Although the training results in a reduction of ROS through adaptations of the antioxidant systems, inadequate exercise training may result in changes in the redox status, oxidative stress $[34,44]$, muscle fatigue, and muscle injury $[1,47,48]$. In addition, during certain types of exercise (especially those involving eccentric contractions), there is a significant release of $\mathrm{Fe}^{2+}$ ions that may aggravate the oxidative stress due to chemical reactivity, culminating in muscle fatigue and damage [43].

Several muscle proteins, including actin, myosin, $\mathrm{Ca}^{2+}$ and $\mathrm{K}^{+}$pumps are sensitive to the redox state, thus changes in ROS or RNS production can directly affect 
muscle contraction [49]. ROS and RNS can induce rises in intracellular $\mathrm{Ca}^{2+}$ (through interaction with $\mathrm{Ca}^{2+}$ channels) and also inactivation of several enzymes from anaerobic and aerobic metabolism, leading to muscle fatigue [50]. Since oxidative stress and excessive inflammation are related to the loss of muscle function, several strategies have been used to improve the muscle and immune cell redox status, using nutritional and anti-oxidant interventions [41].

\section{Redox status: the target for immunonutrition?}

Additionally to the previously cited redox-sensitive proteins, nuclear factor- $\kappa B$ (NF- $\kappa B$ ) is extremely sensitive to the redox status of the cells [51]. This protein is a ubiquitous transcription factor originally discovered in B-lymphocytes, which is essential for inflammatory responses to a variety of signals, immune function, endothelial cell activation, and the control of cell growth. NF- $\mathrm{kB}$ is normally located in the cytoplasm in an inactive form bound to an inhibitory IKB protein. A wide variety of inflammatory stimuli (such as excessive ROS and RNS) can utilize specific signal transducing pathways to enable phosphorylation of IкB by IкB kinase (IKK) and thus ensure its proteasomal degradation [52]. ІКB degradation will release NF- $\mathrm{kB}$, allowing it to translocate to the nucleus and induce pro-inflammatory gene expression. In this way, our cells have very sensitive and responsive control mechanisms for regulating redox status and thus NF- $k B$ activation, to regulate the optimal level of inflammation. The most important intracellular nonenzymatic antioxidants are GSH and its oxidative form GSSG (oxidized glutathione) [1,53].

GSH ( $\gamma$-glutamyl-cysteinyl-glycine) is the predominant low-molecular-weight thiol $(0.5-10 \mathrm{mmol} / \mathrm{L})$ in animal cells. It is now well accepted that many forms of thiol oxidation (disulphide formation, gluathionylation and Snitrosylation) are reversible and can provide a mechanism used by skeletal muscle cells in the regulation of metabolic signaling and transcriptional processes, including in muscle adaptation after exercise and training $[1,54]$. Since the cellular redox state is crucial for several molecular pathways, and glutathione seems to be the key regulator/sensor for redox status, strategies aiming at improving GSH synthesis are now being studied. The synthesis of GSH from glutamate, cysteine, and glycine is catalyzed sequentially by two key cytosolic enzymes, $\gamma$-glutamylcysteine synthetase (GCS) and GSH synthetase (Figure 2). GCS is the key regulatory enzyme, activated by several types of stress including oxidative and nitrosative stress, inflammation, heat stress, and others [55]. It is therefore reasonable to speculate that amino acid and protein supplementation, may provide intracellular GSH precursors - an essential strategy to improve GSH synthesis and redox protection, leading also to better control of the inflammatory status and muscle recovery [56].

However, although antioxidant supplementation may at first be considered as beneficial, the consequent reduction of ROS/RNS could actually have negative effects in non-athletes. Muscle redox state may be best improved by providing skeletal muscle cells with the key natural precursors for GSH synthesis and allowing the cells to synthesize what they actually require. Exerciseinduced ROS is not detrimental to human health, thus endogenous antioxidants may be sufficient to protect against exercise-induced oxidative damage, however this may not be applicable for elite athletes.

In addition to GSH metabolism, the levels of iHSP72 may also be involved in the control of exercise-induced muscle inflammation and adaptation [57]. Their expression has been shown to be induced by a wide range of stressors such as oxidative stress, thermal stress, hypoxia, viral infection, heavy metal contamination, ischemia, exercise metabolic stress and many others [33,53]. As molecular chaperones, the HSP70 family can interact with other proteins (unfolded, in non-native state and/or stress-denatured conformations) to avoid inappropriately interactions, formation of protein aggregates and degradation of damaged proteins, helping the correct refolding of proteins. Other HSP functions include protein translocation, anti-apoptosis, and also anti-inflammatory response [58]. The anti-inflammatory role of the HSP70 is mediated by its interaction with the proteins involved in the activation of the NF- $\mathrm{KB}$, blocking its translocation to the nucleus and slowing of the inflammatory process $[51,58]$. Interestingly, specific amino acid supplementation has been shown to induce HSP70 and GSH in many cells, as will be described below.

\section{Immune mediating effects of L-glutamine}

L-glutamine is probably the most widely recognized immuno-nutrient since it can be used as an oxidizable fuel, a substrate for nucleotide synthesis, a modulator of intermediary metabolism of amino acids [59,60], HSP expression [33] and a component of GSH-mediated antioxidant defense (Figure 2) [44,61], thus serving as a key substrate for cell survival, maintenance and proliferation. The use of L-glutamine as a nutritional supplement for sport and exercise increased in the 90 's, based on several clinical nutritional studies, that found benefits in attenuate the dramatic decrease in plasma and tissues L-glutamine levels [62], as well as immune cell function, including lymphocytes $[8,61]$ and neutrophils $[59,63]$. Several important publications have described the importance of L-glutamine in clinical nutrition $[59,62,64]$.

Oral L-glutamine supplementation $(0.1 \mathrm{~g} / \mathrm{kg}$ body $\mathrm{wt})$ for athletes appeared to have a beneficial effect by attenuating the exercise-induced decrease in plasma L-glutamine 


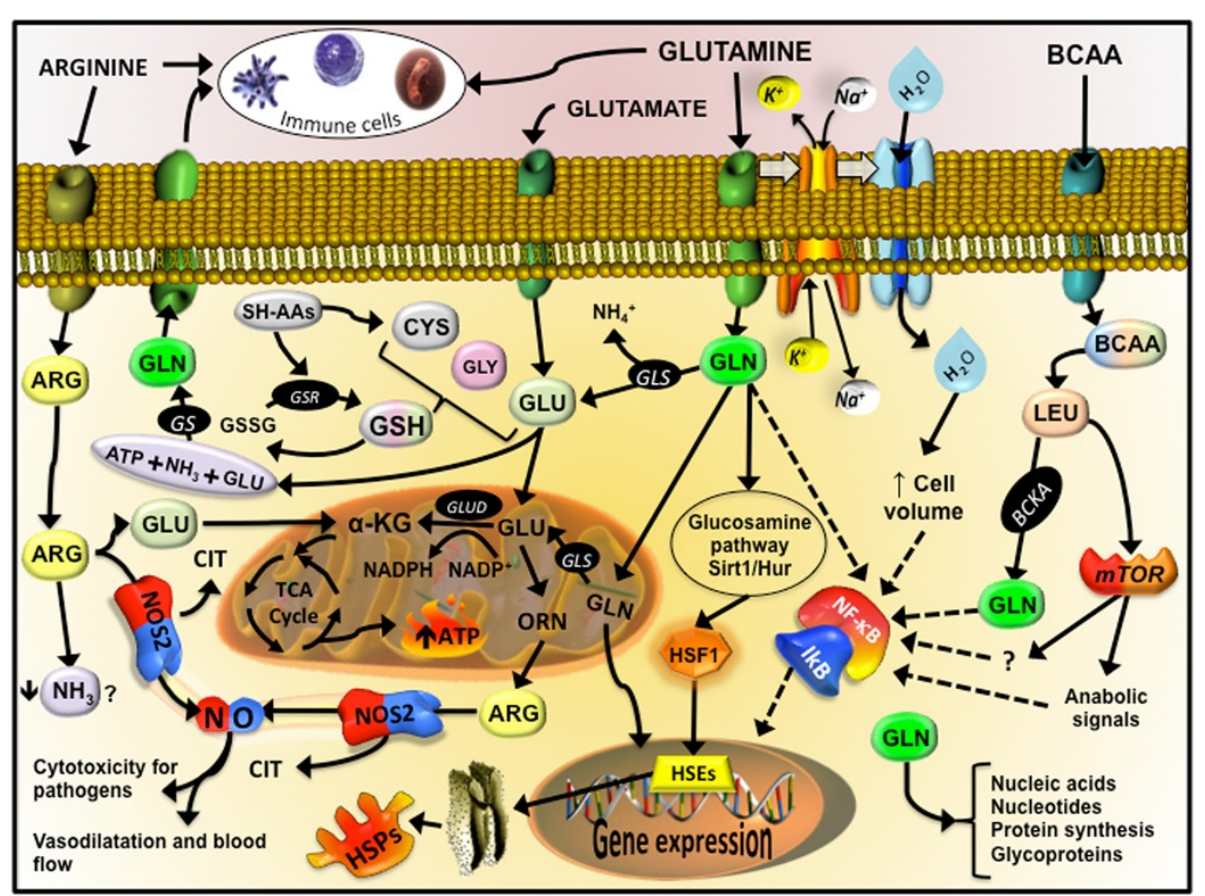

Figure 2 Immune, antioxidant and inflammatory targets that L-glutamine, L-arginine and BCAA are involved. From L-glutamine, glutamate $(G L U)$ is produced through glutaminase activity $(G L S)$, releasing ammonium ion $\left(\mathrm{NH}_{4}^{+}\right)$. Inside of mitochondria or in the cytosol, glutamate from L-glutamine, L-leucine (LEU) or L-arginine (ARG) is an important fuel (ATP) and/or precursor for the synthesis of intermediate metabolism of amino acids such as ornithine (ORN), antioxidant defenses such as glutathione (GSH), anabolic signals through mTOR cascade, and cell repair system such the as the heat shock proteins (HSPs). HSPs are modulated by the heat shock factor 1, which is activated by the glucosamine pathway, sirtuin 1 (Sirt1) and human antigen R (Hur), also known as nutrient sensors. De novo L-glutamine synthesis can occur through L-glutamine synthetase (GS), using glutamate, ATP and ammonia $\left(\mathrm{NH}_{3}\right)$. L-glutamine is transported inside the cell trough active transport with sodium $\left(\mathrm{Na}^{+}\right)$potassium $\left(\mathrm{K}^{+}\right)$ATPase, which augment the absorption of water, altering the volume of the cell and stimulate the resistance to damage. L-arginine availability is important to NO production through nitric oxide synthase 2 (NOS2) and citrulline (CIT). Other Abbreviations: heat shock elements (HSEs); oxidized GSH (GSSG); GSH-S reductase (GSR); glutamate dehydrogenase (GLUD); alpha-ketoglutarato (a-KG).

levels $[4,65]$, the decreased number of lymphocytes, and eventually the risk of URTI's [66]. Nevertheless, the efficacy of L-glutamine supplementation has raised many doubts and controversies, as subsequent studies with fixed (20-30 g/day) or variable $(0.3-0.5 \mathrm{~g} / \mathrm{kg}$ body wt) doses, or even in association with other macronutrients, such carbohydrates, did not report similar outcomes $[12,67,68]$. Possibly, for these reasons the last consensus statement in 2011 did not recommend L-glutamine supplements for sports and exercise [69].

The divergences between the clinical and sport nutrition data resulted on the idea that, perhaps, L-glutamine stores within the body cannot be sufficiently depleted by exercise [69]. Although, the evidences that L-glutamine is a direct modulator of the glutathione (antioxidant properties) and HSPs (with chaperone function and inflammatory control) synthesis (Figure 2) deserve some consideration. Furthermore, when L-glutamine is provided by oral or enteral ways in its free form, the amino acid is highly metabolized by the gut, fact that may explain the lower effect in other tissues and circulating cells, such as the immune cells. A possible alternative way is the exogenous administration of L-glutamine chemically attached to another amino acid (e.g. L-alanine), usually as a dipeptide, such L-alanyl-Lglutamine.

In humans [66] and animal models [70], acute oral L-glutamine supplementation, in its free form or as a dipeptide, is able to increase the plasma L-glutamine concentration between 30 to 120 minutes after ingestion. However, L-glutamine containing dipeptides are highly soluble and stable in solution, often used in enteral nutrition and TPN, and achieve high L-glutamine and L-alanine into the circulation. This effect has been attributed to the glycopeptide transport protein (PepT-1) in the intestinal cells (enterocytes), which have a more efficient transport mechanism for the absorption of dipeptides and tripeptides than for the absorption of free amino acids [71]. In this manner, L-glutamine from dipeptide administration can avoid metabolism by enterocytes, proceeding directly to the systemic circulation [47,72], therefore increasing its availability to immune cells and other tissues [61]. In the dipeptide or in its free form, L-alanine can spare Lglutamine metabolism allowing the latter to be used by high-demand tissues [61]. 
In vivo studies have shown that L-glutamine supplements (free along with L-alanine and glutamine containing dipeptides) are able to increase the hepatic and muscular concentration of L-glutamine, which in turns increases the tissue concentration of GSH, attenuating the oxidative stress induced by long duration physical exercise [44]. This antioxidant effect is attributed to the supply of L-glutamate from L-glutamine, especially from plasma to immune cells and skeletal muscles $[59,60]$. When transported inside the cell, L-glutamine simultaneously promotes the uptake of water, an increase in sodium ion $\mathrm{Na}^{+}$uptake and the release of potassium ions $\left(\mathrm{K}^{+}\right)$, which increase the cell hydration state and volume, which is important in the resistance to injury (Figure 2) [73]. L-glutamine availability increase neutrophil and lymphocyte activity and function [74], for example, generating NADPH for the NADPH oxidase enzyme [63], stimulating intermediary metabolism, and preventing apoptosis by maintaining mitochondrial function $[8,74,75]$. In fact, L-glutamine supplementation may attenuate muscle damage and inflammation (e.g. levels of TNF- $\alpha$ and $\operatorname{PgE}_{2}$ ) induced by exhausting exercise [47].

More recently, several studies have reported glutamineenhanced stimulation of the HSP response induced by acute or chronic inflammation [34,61]. L-glutamine activates intracellular nutrient sensors such as the sirtuins. Specifically sirtuin 1 (SIRT1)/human antigen R (HUR) may be activated through glucosamines [76] leading to activation of the heat shock transcription factor, HSF-1, and the heat shock elements (HSEs) in the nucleus [61], promoting cell survival [76]. SIRT1 acts on many substrates, including histones, forkhead box O (FOXO), $\mathrm{NF} \kappa \mathrm{B}$ and p53 [77]. Moreover, L-glutamine availability is a limiting step for mTOR complex 1 (mTORC1) activation pathway, a major regulator of cell size and tissue mass in both normal and diseased states [78]. Considering the highly evolutionarily conserved HSF-1-HSP70 response (known as the Stress Response), then the tight integration between metabolic (e.g., intermediary amino acid metabolism) and immune signaling leading to optimal responses against pathogens should not be unexpected. In summary, growing evidence in support of the immune mediating effects of L-glutamine, has resulted in an increase in interest for use in supplementation. More studies in athletes are required to determine optimal supplementation strategies, including the use of dipeptides with and without free amino acids.

\section{L-arginine- NO pathway}

Nitric Oxide (NO) plays an important role in many functions in the body regulating vasodilatation and blood flow, inflammation and immune system activation, insulin secretion and sensitivity $[79,80]$, mitochondrial function and neurotransmission. The amino acid L-arginine is the main precursor of $\mathrm{NO}$ via nitric oxide synthase (NOS) activity, thus the availability of this amino acid may modulate $\mathrm{NO}$ production in conditions of competition for this amino acid (Figure 2) [81]. Dietary L-arginine and L-citrulline supplements may increase levels of NO metabolites. Although the effects of L-arginine supplementation has shown positive effects in many conditions such as diabetes [82] and cardiovascular diseases [83], this response has not been directly related to an improvement in performance related to sport and exercise [84]. Many of the positive aspects of L-arginine supplementation are related to improved circulation (due to increased NO levels) in sedentary individuals.

L-arginine supplementation in exercise training has not resulted in clearly defined outcomes. The high variability seems to be attributed to: i) human $v s$. animal models; ii) healthy $v s$. non-healthy subjects; iii) differences in body composition among subjects; iv) individual training status; v) duration of the supplementation and vi) type of exercise.

Although L-arginine can be produced by the adult human body (synthesized from L-glutamine, glutamate, and proline via the intestinal-renal axis in humans and most other mammals) [85], this amino acid is considered as a "conditionally essential" under conditions such as diabetes, additional ingestion may be required to normalize the plasma levels. L-arginine is a known powerful amino acid-based secretagogue for insulin, growth hormone $(\mathrm{GH})$, glucagon and adrenaline [86]. Since this amino acid plays a critical role in cytoplasmic and nuclear protein synthesis, it has been used and suggested as an inductor of muscle growth and immune protection. L-arginine supplementation is known to increase the levels of both $\mathrm{GH}$ and IGF-1 in the blood but reduce IGFBP-3 protein levels [84]. However, most human studies have failed to show that L-arginine can provide improvements in performance in the sport and exercise context [87-90].

An increase in NO may result in improved blood flow and this could potentially be beneficial for individuals engaged in exercise training [90], by increasing nutrient delivery and/or waste-product removal from exercising skeletal muscles [90]. However, L-arginine, NO donors and NOS inhibitors induce effects on blood pressure, heart rate, and blood flow at rest conditions [83], several studies have shown that these agents have no effect on these variables during exercise in humans [83,91]. Even though L-arginine supplementation increases blood flow in basal conditions, the amino acid does not change this variable during exercise. This could indicate that during exercise, other mechanisms of vasodilation in the microcirculation system of active muscles may be involved. There is evidence that vasodilatory prostanoids [92] may be important in determining responses to acetylcholine (Ach) in both diabetic [93] and non-diabetic subjects 
$[94,95]$, their effects mediated through an increase in cyclic AMP.

L-arginine supplementation may improve maximal $\left(\mathrm{VO}_{2 \max }\right.$ test) exercise capacity in patients with cardiovascular disease $[92,96]$. However, in healthy subjects, L-arginine- $\alpha$-ketoglutarate did not influence body composition, muscular strength endurance, or aerobic capacity [97]. The finding that L-arginine- $\alpha$-ketoglutarate supplementation did not improve aerobic capacity supports earlier studies that L-arginine improves $\mathrm{VO}_{2 \max }$ in various disease populations but not in healthy individuals [98]. In addition, L-arginine failed to improve muscular performance and recovery, independently of the training status [90].

Inadequate intake of dietary L-arginine may impair NO synthesis by both constitutive and inducible NOS in mammals [99], indicating a role for L-arginine in immune function. The effects of L-arginine supplementation on lymphocyte count has been reported [100], in a study which determined whether the transient hyperammonemia induced by high-intensity exercise (HI) could influence white blood cell distribution, and whether L-arginine could affect this parameter. Thirty-nine male jiu-jitsu practitioners were submitted to an acute bout of HI exercise using placebo or L-arginine $(100 \mathrm{mg} \cdot \mathrm{kg}-1$ of body mass - day-1). Increases in lymphocyte number and ammonia were simultaneously reduced by L-arginine supplementation. Since the authors did not measure the pre-supplementation levels of L-arginine, it is difficult to know if the effect was induced by the higher levels of the amino acid or only by the correction of lower levels among the athletes.

In conclusion, it is clear that L-arginine supplementation improves exercise capacity and blood flow in conditions associated with endothelial dysfunction, such reduced basal NO production. However, in healthy individuals with normal levels of circulating NO, L-arginine supplementation has little or no effect.

\section{Multiple aspects of BCAA}

From the nine amino acids nutritionally classified as essentials, three of these compounds are the branched chain amino acids (BCAA; L-valine, L-leucine and L-isoleucine). Mostly protein foods, such as meat, poultry, fish, eggs, milk and cheese can containing on average 15 to 20 grams of BCAA per $100 \mathrm{~g}$ of protein [101]. The presence of $\mathrm{BCAA}$ in the most primitive organisms that existed before the complex cellular evolution of higher organisms shows the importance this compounds to the metabolic evolution. BCAA are predominantly metabolized in the skeletal muscle, which means that they escape from liver metabolism and, after ingestion; they rapidly increase their concentration in plasma. Although the liver cannot directly metabolize BCAA, this tissue has an active system for the degradation of the $\alpha$-branched-chain-keto acids (BCKA) derived from the corresponding BCAA [102] through the branched-chain $\alpha$-keto acid dehydrogenase (BCKD), which contribute to gluconeogenesis [76].

Oxidative stress may be one of the underlying links between chronic inflammatory response and skeletal muscle wasting [102,103], a fact that may negatively impact on macrophage and neutrophil function [74], as well as on lymphocyte proliferation [3]. Skeletal muscle cells have high activity of BCAA transaminases and L-glutamine synthetase, key enzymes in the synthesis of L-glutamine and other intermediary amino acids [12]. In this regard, when BCAA is present in the culture medium, lymphocyte proliferation capacity is increased; however, this most likely reflects an inability to synthesize sufficient amino acids and protein required for proliferation [104], which reinforces the important role of skeletal muscle in immune regulation. In animal [105] and human studies [106-108] under catabolic situations, such as infection or malnutrition, BCAA are crucial for the maintenance of immune function [104]. However, in catabolic but nondeficient situations, such as in elite athletes involved in heavy endurance or resistance training, the effects of BCAA administration is still not clear. When a large amount of protein is consumed, typically by athletes, an abundance of dietary BCAA will be available for metabolic and immune requirements (high-quality protein sources range from approximately 18-26\% BCAA [109]).

In one study, acute and chronic BCAA supplementation (about $6 \mathrm{~g} / \mathrm{d}$ ) to endurance athletes resulted in attenuation of the fall in the plasma L-glutamine concentration and also modified the immune suppression promoted by the exercise [107]. Once stimulated through the supplementation of BCAA, cellular L-leucine uptake may enhance the synthesis and availability of L-glutamine by providing glutamate in the intracellular environment. Hence, it is believed that the immune effects of BCAA may be dependent on L-glutamine metabolism in the tissues, such as the skeletal muscle. In fact, in hyper-catabolic situations, such as burning, sepsis and malnutrition, BCAA administration can modulate inflammation through the L-glutamine pathway [110]. However, considering the effects of exercise, this pathway deserves some considerations. When lymphocytes are maintained in vitro in a low level of L-glutamine, identical to the lowest plasma L-glutamine concentration measured post-exercise (300 $400 \mu \mathrm{M})$, these cells perform equally well [59] as when L-glutamine is added at a higher concentration similar to the resting plasma level $(600 \mu \mathrm{M})$ [12]. Consequently, BCAA effects for sports and exercise with regard to immune function, may occur independently of L-glutamine synthesis and stimulation.

Some studies have reported that BCAA administration may attenuate higher inflammatory responses and muscle soreness induced by severe exercise. Prior to resistance 
squat exercise, BCAA supplementation $(100 \mathrm{mg} / \mathrm{kg}$ body weight) was able to reduce the delayed-onset muscle soreness (DOMS) [111]. This effect is due to BCAA oxidation in tissues via generation of BCKA's, such $\alpha$-ketoisocaproate, $\alpha$-keto- $\beta$-methylvalerate and $\alpha$-ketoisovalerate derived from L-leucine, L-isoleucine and L-valine, respectively, and L-glutamine synthesis. BCAA supply and oxidation can inhibit the activity of pyruvate dehydrogenase, a key regulatory site between glycolysis and the citric acid cycle, a mechanism that favors the deviation of pyruvate to the formation of L-alanine which, after release, acts as a precursor in hepatic gluconeogenesis [112]. In fact, in animal studies, chronic supplementation with BCAA promoted a higher hepatic and muscle glycogen synthesis, even after an exhaustive exercise test [112]. L-leucine improved protein synthesis [105] through mTOR stimulation, hVpS34 and calcium-related proteins (Figure 2) [113], not during but after exercise activity [108]. This effect can limit the excessive activation of NF- $\mathrm{KB}$, attenuating the uncontrolled inflammation and its effects, which include the DOMS.

Another possible protective mechanism of BCAA may be mediated through the antioxidant system. It has been shown that BCAA supplementation increased the expression of genes involved in the antioxidant defense, such superoxide dismutase (SOD) 1 and 2, catalase (CAT) and glutathione peroxidase 1 (GPx1) in trained middle-aged mice. Moreover, the same work reported reductions in oxidative stress in cardiac and skeletal muscle [110]. This led to the idea that redox balance can be a target for the potential benefits promoted by BCAA administration. In fact, BCAA and BCAA along with other sulphur-containing amino acids, such L-taurine, attenuated the DOMS and muscle damage induced by eccentric exercise [114].

The multiple aspects of BCAA, particularly L-leucine has shed light on their possible roles in metabolic disease. Of the BCAA only L-leucine has potent effects upon protein turnover (i.e. stimulates protein synthesis and inhibits protein degradation) via mTOR downstream pathways, thus inadequate ingestion of L-leucine may decrease relative concentrations of L-valine and L-isoleucine. This effect negatively impacts on protein turnover and is called L-leucine paradox, which may be explained by an imbalance of BCAA oxidation in the tricarboxylic acid cycle (TCA) via BCKD complex and anaplerosis reactions. The close relationship between BCAA and its participation in cell bioenergetics and oxidative metabolism may promote an insulinotropic effect in pancreatic $\beta$-cells [76]. Conversely, BCAA catabolism is associated with decreased insulin sensitivity in obese patients, fact that corroborates with animal models with excess intake of BCAA and lipids. In this scenario, BCAA catabolism, especially in muscle and liver would result in increased propionyl and succinyl CoA synthesis, leading to incomplete oxidation of fatty acids. In conclusion, while progress has been made, more studies are needed to establish the crosstalk between lipids and BCAA, as well as BCAA roles in metabolic dysfunctions [115].

\section{Whey proteins as an amino acid source}

The constituents of milk have become recognized as functional foods, with direct impact on human health. Milk has two primary 'fractions' of proteins: caseins and whey. Whey is the liquid portion that represents $\sim 20 \%$ of the total protein content of bovine milk [116]. The advances in food processing, such ultrafiltration and microfiltration have resulted in the development of different whey protein products from dairy plants worldwide. The most well known whey proteins are: concentrate (about 80-95\% of protein, with or without lactose), isolate (about 90-95\% of protein, normally without carbohydrates), hydrolysed (smaller peptide fractions, reduce immunological reactions, such allergy) and non-denatured (native protein structures) [117]. Furthermore, whey proteins with casein, albumin and/or soy protein, commonly called blend products can be found in retail stores. For more details see Marshall [117] and Luhovyy, Akhavan [118].

Although whey proteins are considered as nutritional supplements, which means extra to the diet, the amino acid composition is very similar to that found in the skeletal muscles, providing almost all of the amino acids in approximate proportion to their ratios $[119,120]$. Hence, these products are incorporated in the diet and not provided extra to the meal protein composition (e.g. meats plus whey). Accordingly, whey proteins it's more likely a complement, than a supplement. Moreover, the components of whey include beta-lactoglobulin, alpha-lactalbumin, bovine serum albumin, lactoferrin, immunoglobulins (e.g. IgA), lactoperoxidase enzymes, glycomacropeptides, vitamins such as vitamin $\mathrm{D}$, and minerals such as $\mathrm{Ca}^{2+}[117,121]$. Lactoferrin and lactoferricin, demonstrate anti-microbial activity; lysosome, lactoperoxidase and diverse globulins and peptides provide a synergistic protective "cocktail" activity against viral and bacterial organisms [121]. In some chronic diseases with high inflammatory profile and adiposity, whey proteins have been used as adjuvant therapy acting in calcitropic hormones, such parathyroid hormone and 1,25 dihydroxycholecalciferol (1,25 - (OH 2)-D) [121]. Alone or combined with an exercise intervention whey studies demonstrate enhancements in energy loss through faecal fat excretion [122], regulation of glucose homeostasis [123] and adipogenesis [121], resulting in an anti- inflammatory effect (Figure 3) [124].

Whey protein supplements are considered also as a cocktail of amino acids, since they contain up to $26 \%$ of BCAA, plus L-arginine, L-lysine, L-glutamine, among others. Thus, the effects of whey protein in the immune 


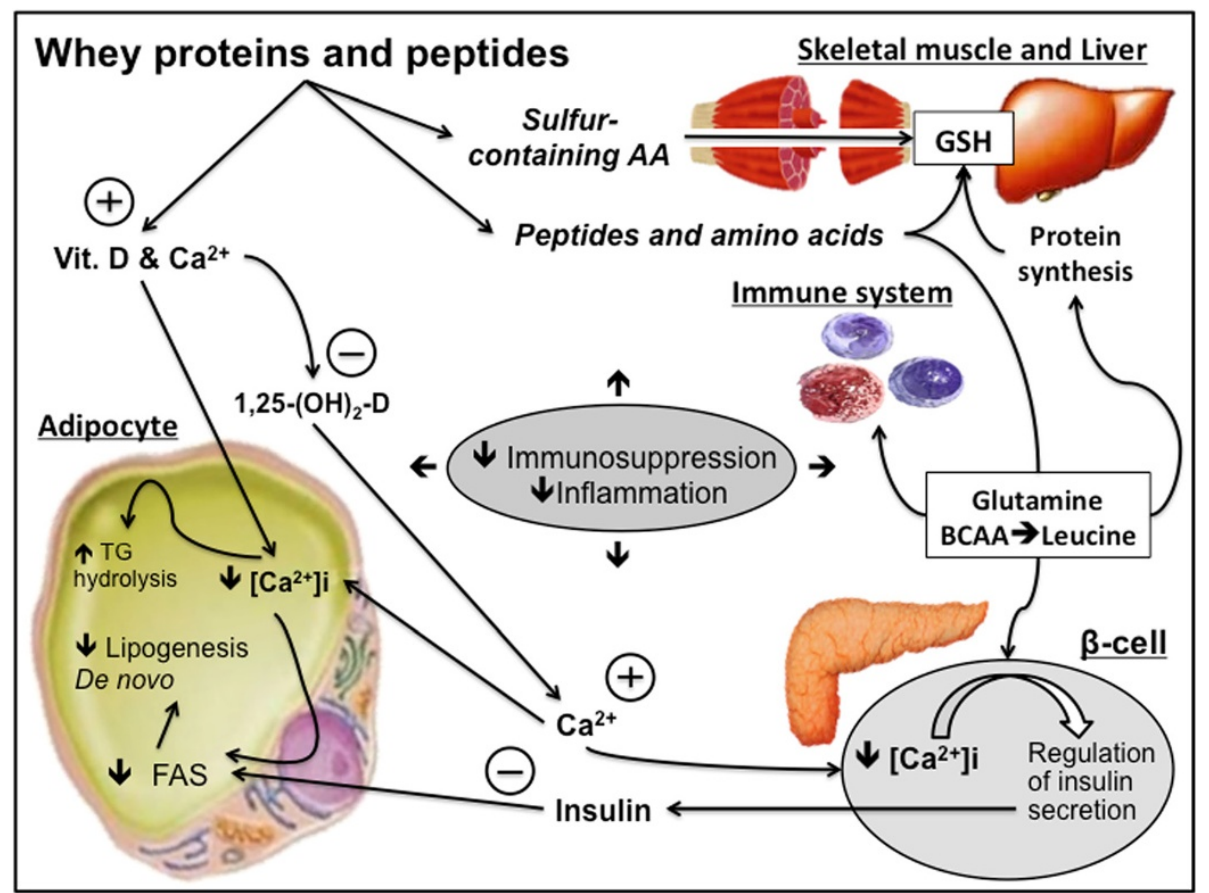

Figure 3 Mechanisms involving whey proteins as a source of different immuno-nutrients. Whey proteins can influence lipid metabolism, muscle protein synthesis/breakdown, antioxidant system, mediated by GSH. Abbreviations: Calcium $\left(\mathrm{Ca}^{2+}\right), 1,25$ Hydroxycholecalciferol $\left(1,25-(\mathrm{OH})_{2}-\right.$ D), intracellular Calcium concentration ([Ca $\left.\left.{ }^{2+}\right] \mathrm{i}\right)$, Fatty Acid Synthase (FAS), Triacylglycerols (TGs).

system may represent the effect of particular amino acids per se. Moreover, whey proteins are rapidly digested and absorbed, resulting postprandial muscle protein synthesis $[125,126]$. Several studies observed changes in muscle growth and performance increments with the chronic ingestion of whey protein supplements [121,127,128]. In one study, triathletes subjected to exhaustive exercise, exhibited a decreased mitochondrial transmembrane potential in both lymphocytes and neutrophils, which leads to apoptotic death and DNA fragmentation [8]. When whey protein enriched with L-glutamine is supplemented, this scenario is reversed, especially in lymphocytes [8], essential for the response against viral infections, such as URTI. On the other hand, the rapid absorption of whey products from the gut, and the hyperaminoacidemia is not the only critical characteristic for maximizing muscle protein synthesis. The time that amino acids are maintained in plasma is also important for the muscle protein turnover, providing gains in muscle mass. There are few studies comparing protein mixtures. Reidy, Walker [129] showed that a blend of whey and soy protein prolonged the elevation in blood amino acid levels after ingestion, when compared to whey protein alone, promoting a greater total muscle protein synthesis measured by the protein fractional synthetic rate (FSR). This is in agreement with other works, which found higher nitrogen retention, and less oxidation with whey blends combined with slowly digested protein, such as casein [130]. Stimulating post-exercise muscle protein synthesis and amino acid concentration maintenance, may also contribute to immune function however, more studies are needed.

The amino acid profile of whey protein supplements also includes sulphur-containing amino acids, such cysteine and taurine [121]. The high proportion of amino donors of sulfhydryl groups may attenuate the reduction of intracellular GSH concentration induced by intensive exercise [128]. Since immune cells, such as lymphocytes can be sensitive to a range of intracellular sulfhydryl compounds, such GSH and cysteine (Figure 2), whey supplementation may not only attenuate the oxidative stress induced by exercise but also help the maintenance of the redox status in immune cells. Experimental evidence support this mechanistic effect [117]. In a recent study, it was observed that the fall in the GHS content, in trained subjects submitted to an intense exercise program (4 weeks), have occurred in parallel with a decline in lymphocytes number. However, this scenario was reversed by $\mathrm{N}$-acetyl-cysteine supplementation [131]. Furthermore, whey protein can act as an immune modulator through other mechanisms, such as L-glutamine, which is critical for the L-glutamine-GSH axis (Figure 3). Collectively, whey proteins via provision of an amino acid cocktail, exert per se an immune function through redox regulations pathways, and this seems particularly important in 
individuals engaged in intense and exhaustive exercise training programs, such elite athletes.

\section{Conclusion}

Immunonutrition for clinical applications to sports activities represents an emerging area for health, especially regarding supply of proteins and amino acids, since they are required for the optimal synthesis and concentration of a variety of immune related proteins (including cytokines and antibodies). Amino acids will feed into and impact on the regulation of key metabolic pathways in immune cells and the cellular oxidative stress response. At the anti-inflammatory molecular level, new findings have been reported such as enhancement of HSP levels, NO synthesis, and GSH/GSSG regulation, all essential for optimal immune function and recovery from intense periods of training.

\section{Competing interest}

The authors declare that they have no competing interest.

\section{Authors' contribution}

This review was designed by VFC; manuscript preparation and written were undertaken by VFC, MK and PN; figures preparation were made by VFC; supervision of the manuscript was made by PN and MK. All authors approved the final version of the paper.

\section{Acknowledgments}

The authors thank the School of Biomedical Sciences, Curtin University, Perth, Western Australia for provision of excellent research facilities and the Brazilian National Council for Scientific and Technological Development (CNPq - Science Without Borders Programme, process 245562/2012-5).

\section{Author details}

${ }^{1} \mathrm{CHIRI}$ Biosciences Research Precinct, Faculty of Health Sciences, School of Biomedical Sciences, Curtin University, GPO Box U1987, Perth, Western Australia, Australia. ${ }^{2}$ Laboratory of Cellular Physiology, Department of Physiology, Institute of Basic Health Sciences, Federal University of Rio Grande do Sul, Porto Alegre, RS, Brazil.

Received: 2 August 2014 Accepted: 4 December 2014 Published online: 14 December 2014

\section{References}

1. Finaud J, Lac G, Filaire E: Oxidative stress: relationship with exercise and training. Sports Med 2006, 36:327-358.

2. Gleeson M: Immune function in sport and exercise. J App/ Physio/ 2007, 103:693-699.

3. Tanskanen M, Atalay M, Uusitalo A: Altered oxidative stress in overtrained athletes. J Sports Sci 2010, 28:309-317.

4. Gleeson M, Nieman DC, Pedersen BK: Exercise, nutrition and immune function. J Sports Sci 2004, 22:115-125.

5. Kreher JB, Schwartz JB: Overtraining syndrome: a practical guide. Sports Health 2012, 4:128-138.

6. Zelig R, Rigassio Radler D: Understanding the properties of common dietary supplements: clinical implications for healthcare practitioners. Nutr Clin Pract 2012, 27:767-776.

7. Nieper A: Nutritional supplement practices in UK junior National track and field athletes. Br J Sports Med 2005, 39:645-649.

8. Cury-Boaventura MF, Levada-Pires AC, Folador A, Gorjao R, Alba-Loureiro TC, Hirabara SM, Peres FP, Silva PR, Curi R, Pithon-Curi TC: Effects of exercise on leukocyte death: prevention by hydrolyzed whey protein enriched with glutamine dipeptide. Eur J Appl Physiol 2008, 103:289-294.

9. Nogiec CD, Kasif S: To supplement or not to supplement: a metabolic network framework for human nutritional supplements. PLoS One 2013, 8:e68751.
10. Crook EM, Hopkins FG: Further observations on the system ascorbic acid-glutathione-ascorbic acid-oxidase. Biochem J 1938, 32:1356-1363.

11. Satyaraj E: Emerging paradigms in immunonutrition. Top Companion Anim Med 2011, 26:25-32

12. Hiscock N, Pedersen BK: Exercise-induced immunodepression- plasma glutamine is not the link. J Appl Physiol 2002, 93:813-822.

13. Costa Rosa LF: Exercise as a time-conditioning effector in chronic disease: a complementary treatment strategy. Evid Based Complement Alternat Med 2004, 1:63-70.

14. Cannon JG: Inflammatory cytokines in nonpathological States. News Physiol Sci 2000, 15:298-303.

15. Drenth JP, Van Uum SH, Van Deuren M, Pesman GJ, Van der Ven-Jongekrijg J, Van der Meer JW: Endurance run increases circulating IL-6 and IL-1ra but downregulates ex vivo TNF-alpha and IL-1 beta production. J App/ Physiol 1995, 79:1497-1503.

16. Nieman DC, Pedersen BK: Exercise and immune function. Recent developments. Sports Med 1999, 27:73-80.

17. Rohde TMD, Richter EA, Kiens B, Pedersen BK: Prolonged submaximal eccentric exercise is associated with increased levels of plasma IL-6. Am J Physiol 1997, 273:E85-E91.

18. Ostrowski K, Rohde T, Asp S, Schjerling P, Pedersen BK: Pro- and anti-inflammatory cytokine balance in strenuous exercise in humans. J Physiol 1999, 515(Pt 1):287-291.

19. Brenner IK, Natale VM, Vasiliou P, Moldoveanu Al, Shek PN, Shephard RJ: Impact of three different types of exercise on components of the inflammatory response. Eur J Appl Physiol Occup Physiol 1999, 80:452-460.

20. Smith LL, Anwar A, Fragen M, Rananto C, Johnson R, Holbert D: Cytokines and cell adhesion molecules associated with high-intensity eccentric exercise. Eur J Appl Physiol 2000, 82:61-67.

21. Malm C: Exercise immunology: the current state of man and mouse. Sports Med 2004, 34:555-566.

22. Petersen EW, Ostrowski K, Ibfelt T, Richelle M, Offord E, Halkjaer-Kristensen J, Pedersen BK: Effect of vitamin supplementation on cytokine response and on muscle damage after strenuous exercise. Am J Physiol Cell Physiol 2001, 280:C1570-C1575.

23. Toft $A D$, Jensen $L B$, Bruunsgaard $H$, Ibfelt $T$, Halkjaer-Kristensen J, Febbraio $M$, Pedersen BK: Cytokine response to eccentric exercise in young and elderly humans. Am J Physiol Cell Physiol 2002, 283:C289-C295.

24. Nieman DC, Henson DA, McAnulty SR, McAnulty LS, Morrow JD, Ahmed A, Heward CB: Vitamin E and immunity after the Kona Triathlon World Championship. Med Sci Sports Exerc 2004, 36:1328-1335.

25. Suzuki K, Nakaji S, Kurakake S, Totsuka M, Sato K, Kuriyama T, Fujimoto H, Shibusawa K, Machida K, Sugawara K: Exhaustive exercise and type-1/type-2 cytokine balance with special focus on interleukin-12 p40/p70. Exerc Immunol Rev 2003, 9:48-57.

26. Petersen AM, Pedersen BK: The anti-inflammatory effect of exercise. J App/ Physiol 2005, 98:1154-1162.

27. Febbraio MA, Steensberg A, Walsh R, Koukoulas I, van Hall G, Saltin B, Pedersen BK: Reduced glycogen availability is associated with an elevation in HSP72 in contracting human skeletal muscle. J Physio/ 2002, 538:911-917.

28. Pedersen BK, Steensberg A, Schjerling P: Muscle-derived interleukin-6: possible biological effects. J Physiol 2001, 536:329-337.

29. Krause M, Keane K, Rodrigues-Krause J, Crognale D, Egan B, De Vito G, Murphy C, Newsholme P: Elevated levels of extracellular heat-shock protein 72 (eHSP72) are positively correlated with insulin resistance in vivo and cause pancreatic beta-cell dysfunction and death in vitro. Clin Sci 2014, 126:739-752.

30. Krause M, Rodrigues-Krause Jda C: Extracellular heat shock proteins (eHSP70) in exercise: possible targets outside the immune system and their role for neurodegenerative disorders treatment. Med Hypotheses 2011, 76:286-290.

31. Hooper PL, Balogh G, Rivas E, Kavanagh K, Vigh L: The importance of the cellular stress response in the pathogenesis and treatment of type 2 diabetes. Cell Stress Chaperones 2014, 19(4):447-464.

32. Krause Mda S, de Bittencourt PI Jr: Type 1 diabetes: can exercise impair the autoimmune event? The L-arginine/glutamine coupling hypothesis. Cell Biochem Funct 2008, 26:406-433.

33. Heck TG, Scholer CM, de Bittencourt PI: HSP70 expression: does it a novel fatigue signalling factor from immune system to the brain? Cell Biochem Funct 2011, 29:215-226. 
34. Petry ER, Cruzat VF, Heck TG, Leite JS, Homem de Bittencourt PI Jr, Tirapegui $\mathrm{J}$ : Alanyl-glutamine and glutamine plus alanine supplements improve skeletal redox status in trained rats: involvement of heat shock protein pathways. Life Sci 2014, 94:130-136.

35. Ziemann E, Zembron-Lacny A, Kasperska A, Antosiewicz J, Grzywacz T, Garsztka T, Laskowski R: Exercise training-induced changes in inflammatory mediators and heat shock proteins in young tennis players. J Sports Sci Med 2013, 12:282-289.

36. Gibson OR, Dennis A, Parfitt T, Taylor L, Watt PW, Maxwell NS: Extracellular Hsp72 concentration relates to a minimum endogenous criteria during acute exercise-heat exposure. Cell Stress Chaperones 2014, 19:389-400.

37. Fehrenbach E, Niess AM, Voelker K, Northoff H, Mooren FC: Exercise intensity and duration affect blood soluble HSP72. Int J Sports Med 2005, 26:552-557.

38. Hunter-Lavin C, Davies EL, Bacelar MM, Marshall MJ, Andrew SM, Williams $J \mathrm{H}$ : Hsp70 release from peripheral blood mononuclear cells. Biochem Biophys Res Commun 2004, 324:511-517.

39. Ireland HE, Leoni F, Altaie O, Birch CS, Coleman RC, Hunter-Lavin C, Williams $\mathrm{JH}$ : Measuring the secretion of heat shock proteins from cells. Methods 2007, 43:176-183.

40. Sorichter S, Koller A, Haid C, Wicke K, Judmaier W, Werner P, Raas E: Light concentric exercise and heavy eccentric muscle loading: effects on CK, MRI and markers of inflammation. Int J Sports Med 1995, 16:288-295.

41. Bryer SC, Goldfarb AH: Effect of high dose vitamin C supplementation on muscle soreness, damage, function, and oxidative stress to eccentric exercise. Int J Sport Nutr Exerc Metab 2006, 16:270-280.

42. Peake JM, Nosaka K, Muthalib M, Suzuki K: Systemic inflammatory responses to maximal versus submaximal lengthening contractions of the elbow flexors. Exerc Immunol Rev 2006, 12:72-85.

43. Niess AM, Simon P: Response and adaptation of skeletal muscle to exercise-the role of reactive oxygen species. Front Biosci 2007, 12:4826-4838.

44. Cruzat VF, Tirapegui J: Effects of oral supplementation with glutamine and alanyl-glutamine on glutamine, glutamate, and glutathione status in trained rats and subjected to long-duration exercise. Nutrition 2009, 25:428-435.

45. Pedersen BKOK, Rohde $T$, Bruunsgaard $H$ : The cytokine response to strenuous exercise. Can J Physiol Pharmacol 1998, 76:505-511.

46. Rodrigues-Krause J, Krause M, Cunha Gdos S, Perin D, Martins JB, Alberton $\mathrm{CL}$, Schaun Ml, De Bittencourt PI Jr, Reischak-Oliveira A: Ballet dancers cardiorespiratory, oxidative and muscle damage responses to classes and rehearsals. Eur J Sport Sci 2014, 14:199-208.

47. Cruzat VF, Rogero MM, Tirapegui J: Effects of supplementation with free glutamine and the dipeptide alanyl-glutamine on parameters of muscle damage and inflammation in rats submitted to prolonged exercise. Cell Biochem Funct 2010, 28:24-30.

48. Palazzetti S, Richard MJ, Favier A, Margaritis I: Overloaded training increases exercise-induced oxidative stress and damage. Can J App/ Physiol 2003, 28:588-604.

49. Reid MB: Free radicals and muscle fatigue: of ROS, canaries, and the IOC Free Radic Biol Med 2008, 44:169-179.

50. Duhamel TA, Green HJ, Perco JG, Ouyang J: Metabolic and sarcoplasmic reticulum $\mathrm{Ca} 2+$ cycling responses in human muscle 4 days following prolonged exercise. Can J Physiol Pharmacol 2005, 83:643-655.

51. Silveira EM, Rodrigues MF, Krause MS, Vianna DR, Almeida BS, Rossato JS, Oliveira LP Jr, Curi R, de Bittencourt PI Jr: Acute exercise stimulates macrophage function: possible role of NF-kappaB pathways. Cell Biochem Funct 2007, 25:63-73.

52. Pillon NJ, Bilan PJ, Fink LN, Klip A: Cross-talk between skeletal muscle and immune cells: muscle-derived mediators and metabolic implications. Am J Physiol Endocrinol Metab 2013, 304:E453-E465.

53. Krause MS, Oliveira LP Jr, Silveira EM, Vianna DR, Rossato JS, Almeida BS, Rodrigues MF, Fernandes AJ, Costa JA, Curi R, De Bittencourt PI Jr: MRP1/GS-X pump ATPase expression: is this the explanation for the cytoprotection of the heart against oxidative stress-induced redox imbalance in comparison to skeletal muscle cells? Cell Biochem Funct 2007, 25:23-32.

54. Ji LL: Modulation of skeletal muscle antioxidant defense by exercise: Role of redox signaling. Free Radic Biol Med 2008, 44:142-152.

55. Wu G, Fang YZ, Yang S, Lupton JR, Turner ND: Glutathione metabolism and its implications for health. J Nutr 2004, 134:489-492.
56. Newsholme P, Krause M, Newsholme EA, Stear SJ, Burke LM, Castell LM: BJSM reviews: $A$ to $Z$ of nutritional supplements: dietary supplements, sports nutrition foods and ergogenic aids for health and performance-part 18. Br J Sports Med 2011, 45:230-232.

57. Rodrigues-Krause J, Krause M, O'Hagan C, De Vito G, Boreham C, Murphy C, Newsholme P, Colleran G: Divergence of intracellular and extracellular HSP72 in type 2 diabetes: does fat matter? Cell Stress Chaperones 2012 17:293-302.

58. Homem de Bittencourt PI Jr, Lagranha DJ, Maslinkiewicz A, Senna SM, Tavares AM, Baldissera LP, Janner DR, Peralta JS, Bock PM, Gutierrez LL, Scola G, Heck TG, Krause MS, Cruz LA, Abdalla DS, Lagranha CJ, Lima T, Curi R: LipoCardium: endothelium-directed cyclopentenone prostaglandin-based liposome formulation that completely reverses atherosclerotic lesions. Atherosclerosis 2007, 193:245-258.

59. Newsholme P: Why is L-glutamine metabolism important to cells of the immune system in health, postinjury, surgery or infection? J Nutr 2001, 131:2515S-2522S. discussion 2523S-2514S.

60. Curi R, Newsholme P, Procopio J, Lagranha C, Gorjao R, Pithon-Curi TC: Glutamine, gene expression, and cell function. Front Biosci 2007, 12:344-357

61. Cruzat VF, Pantaleao LC, Donato J Jr, de Bittencourt PI Jr, Tirapegui J: Oral supplementations with free and dipeptide forms of L-glutamine in endotoxemic mice: effects on muscle glutamine-glutathione axis and heat shock proteins. J Nutr Biochem 2014, 25:345-352.

62. Wernerman J: Clinical use of glutamine supplementation. J Nutr 2008 138:2040S-2044S

63. Pithon-Curi TC, Schumacher Rl, Freitas JJ, Lagranha C, Newsholme P, Palanch AC, Doi SQ, Curi R: Glutamine delays spontaneous apoptosis in neutrophils. Am J Physio/ Cell Physiol 2003, 284:C1355-C1361.

64. Roth E: Nonnutritive effects of glutamine. J Nutr 2008, 138:2025S-2031S.

65. Hiscock N, Petersen EW, Krzywkowski K, Boza J, Halkjaer-Kristensen J, Pedersen BK: Glutamine supplementation further enhances exercise-induced plasma IL-6. J Appl Physiol 2003, 95:145-148.

66. Castell LM, Newsholme EA: The effects of oral glutamine supplementation on athletes after prolonged, exhaustive exercise. Nutrition 1997, 13:738-742.

67. Castell LM, Poortmans JR, Leclercq R, Brasseur M, Duchateau J, Newsholme EA: Some aspects of the acute phase response after a marathon race, and the effects of glutamine supplementation. Eur J Appl Physiol Occup Physiol 1997, 75:47-53.

68. Krzywkowski K, Petersen EW, Ostrowski K, Kristensen JH, Boza J, Pedersen BK Effect of glutamine supplementation on exercise-induced changes in lymphocyte function. Am J Physiol Cell Physiol 2001, 281:C1259-C1265.

69. Walsh NP, Gleeson M, Pyne DB, Nieman DC, Dhabhar FS, Shephard RJ, Oliver SJ, Bermon S, Kajeniene A: Position statement. Part two: maintaining immune health. Exerc Immunol Rev 2011, 17:64-103.

70. Rogero MM, Tirapegui J, Pedrosa RG, Pires ISD, de Castro IA: Plasma and tissue glutamine response to acute and chronic supplementation with L-glutamine and L-alanyl-L-glutamine in rats. Nutr Res 2004, 24:261-270.

71. Nässl A-M, Rubio-Aliaga I, Fenselau H, Marth MK, Kottra G, Daniel H: Amino acid absorption and homeostasis in mice lacking the intestinal peptide transporter PEPT1. Am J Physiol Gastrointest Liver Physiol 2011, 301:G128-G137.

72. Rogero MM, Tirapegui J, Pedrosa RG, de Castro IA, Pires ISD: Effect of alanyl-glutamine supplementation on plasma and tissue glutamine concentrations in rats submitted to exhaustive exercise. Nutrition 2006, 22:564-571.

73. Usher-Smith JA, Huang CLH, Fraser JA: Control of cell volume in skeletal muscle. Biol Rev Camb Philos Soc 2009, 84:143-159.

74. Pithon-Curi TC, Trezena AG, Tavares-Lima W, Curi R: Evidence that glutamine is involved in neutrophil function. Cell Biochem Funct 2002, 20:81-86.

75. Cury-Boaventura MF, Peres FP, Levada-Pires AC, Silva PRS, Curi R, Pithon-Curi TC: Effect of supplementation with hydrolyzed whey protein enriched with glutamine dipeptide on performance of triathletes. Med Sci Sport Exer 2008, 40:S102-S103.

76. Newsholme P, Cruzat V, Arfuso F, Keane K: Nutrient regulation of insulin secretion and action. J Endocrinol 2014, 221:R105-R120.

77. Kotas ME, Gorecki MC, Gillum MP: Sirtuin-1 is a nutrient-dependent modulator of inflammation. Adipocyte 2013, 2:113-118.

78. Nicklin $\mathrm{P}$, Bergman $\mathrm{P}$, Zhang $\mathrm{B}$, Triantafellow $\mathrm{E}$, Wang $\mathrm{H}$, Nyfeler $\mathrm{B}$, Yang $\mathrm{H}$, Hild M, Kung C, Wilson C, Myer VE, MacKeigan JP, Porter JA, Wang YK, Cantley LC, Finan PM, Murphy LO: Bidirectional transport of amino acids regulates mTOR and autophagy. Cell 2009, 136:521-534 
79. Krause M, Rodrigues-Krause J, O'Hagan C, De Vito G, Boreham C, Susta D, Newsholme P, Murphy C: Differential nitric oxide levels in the blood and skeletal muscle of type 2 diabetic subjects may be consequence of adiposity: a preliminary study. Metabolism 2012, 61:1528-1537.

80. Krause MS, McClenaghan NH, Flatt PR, de Bittencourt PI, Murphy C, Newsholme P: L-arginine is essential for pancreatic beta-cell functional integrity, metabolism and defense from inflammatory challenge. J Endocrinol 2011, 211:87-97.

81. Newsholme P, Homem De Bittencourt PI, OH C, De Vito G, Murphy C, Krause MS: Exercise and possible molecular mechanisms of protection from vascular disease and diabetes: the central role of ROS and nitric oxide. Clin Sci (Lond) 2009, 118:341-349.

82. Lucotti P, Setola E, Monti LD, Galluccio E, Costa S, Sandoli EP, Fermo I, Rabaiotti G, Gatti R, Piatti P: Beneficial effects of a long-term oral L-arginine treatment added to a hypocaloric diet and exercise training program in obese, insulin-resistant type 2 diabetic patients. Am J Physiol Endocrinol Metab 2006, 291:E906-E912.

83. Fayh AP, Krause M, Rodrigues-Krause J, Ribeiro JL, Ribeiro JP, Friedman R, Moreira JC, Reischak-Oliveira A: Effects of L-arginine supplementation on blood flow, oxidative stress status and exercise responses in young adults with uncomplicated type I diabetes. Eur J Nutr 2013, 52:975-983.

84. Zajac A, Poprzecki S, Zebrowska A, Chalimoniuk M, Langfort J: Arginine and ornithine supplementation increases growth hormone and insulin-like growth factor- 1 serum levels after heavy-resistance exercise in strength-trained athletes. J Strength Cond Res 2010, 24:1082-1090

85. Newsholme P, Stenson L, Sulvucci M, Sumayao R, Krause M: Amino Acid Metabolism. Secondth edition. Elsevier; 2011.

86. McConell GK: Effects of L-arginine supplementation on exercise metabolism Curr Opin Clin Nutr Metab Care 2007, 10:46-51.

87. Alvares TS, Conte CA, Paschoalin VM, Silva JT, Meirelles Cde M, Bhambhani YN, Gomes PS: Acute I-arginine supplementation increases muscle blood volume but not strength performance. Appl Physiol Nutr Metab 2012, 37:115-126

88. Greer BK, Jones BT: Acute arginine supplementation fails to improve muscle endurance or affect blood pressure responses to resistance training. J Strength Cond Res 2011, 25:1789-1794.

89. Tang JE, Lysecki PJ, Manolakos JJ, MacDonald MJ, Tarnopolsky MA, Phillips SM: Bolus arginine supplementation affects neither muscle blood flow nor muscle protein synthesis in young men at rest or after resistance exercise. J Nutr 2011, 141:195-200.

90. Wax B, Kavazis AN, Webb HE, Brown SP: Acute L-arginine alpha ketoglutarate supplementation fails to improve muscular performance in resistance trained and untrained men. J Int Soc Sports Nutr 2012, 9:17.

91. Bradley SJ, Kingwell BA, McConell GK: Nitric oxide synthase inhibition reduces leg glucose uptake but not blood flow during dynamic exercise in humans. Diabetes 1999, 48:1815-1821.

92. Cheng JW, Baldwin SN: L-arginine in the management of cardiovascular diseases. Ann Pharmacother 2001, 35:755-764.

93. Poston L, Taylor PD: Glaxo/MRS Young Investigator Prize. Endothelium-mediated vascular function in insulin-dependent diabetes mellitus. Clin Sci (Lond) 1995, 88:245-255.

94. Kilbom A, Wennmalm A: Endogenous prostaglandins as local regulators of blood flow in man: effect of indomethacin on reactive and functional hyperaemia. J Physiol 1976, 257:109-121.

95. Cowley AJ, Stainer K, Rowley JM, Wilcox RG: Effect of aspirin and indomethacin on exercise-induced changes in blood pressure and limb blood flow in normal volunteers. Cardiovasc Res 1985, 19:177-180.

96. Nagaya N, Uematsu M, Oya H, Sato N, Sakamaki F, Kyotani S, Ueno K, Nakanishi N, Yamagishi M, Miyatake K: Short-term oral administration of L-arginine improves hemodynamics and exercise capacity in patients with precapillary pulmonary hypertension. Am J Respir Crit Care Med 2001, 163:887-891.

97. Campbell B, Roberts M, Kerksick C, Wilborn C, Marcello B, Taylor L, Nassar E, Leutholtz B, Bowden R, Rasmussen C, Greenwood M, Kreider R: Pharmacokinetics, safety, and effects on exercise performance of L-arginine alpha-ketoglutarate in trained adult men. Nutrition 2006, 22:872-881

98. Abel T, Knechtle B, Perret $C$, Eser $\mathrm{P}$, von Arx P, Knecht $\mathrm{H}$ : Influence of chronic supplementation of arginine aspartate in endurance athletes on performance and substrate metabolism - a randomized, double-blind, placebo-controlled study. Int J Sports Med 2005, 26:344-349.
99. Flynn NE, Meininger CJ, Haynes TE, Wu G: The metabolic basis of arginine nutrition and pharmacotherapy. Biomed Pharmacother 2002, 56:427-438

100. Goncalves LC, Bessa A, Freitas-Dias R, Luzes R, Werneck-de-Castro JP, Bassini A, Cameron LC: A sportomics strategy to analyze the ability of arginine to modulate both ammonia and lymphocyte levels in blood after high-intensity exercise. J Int Soc Sports Nutr 2012, 9:30.

101. Burke LM, Castell LM, Stear SJ, Rogers PJ, Blomstrand E, Gurr S, Mitchell N, Stephens FB, Greenhaff PL: A-Z of nutritional supplements: dietary supplements, sports nutrition foods and ergogenic aids for health and performance Part 4. Br J Sports Med 2009, 43:1088-1090.

102. Nicastro $H$, da Luz CR, Chaves DF, Bechara LR, Voltarelli VA, Rogero MM, Lancha AH Jr: Does branched-chain amino acids supplementation modulate skeletal muscle remodeling through inflammation modulation? Possible mechanisms of action. J Nutr Metab 2012, 2012:136937.

103. Tisdale MJ: Is there a common mechanism linking muscle wasting in various disease types? Curr Opin Support Palliat Care 2007, 1:287-292.

104. Li P, Yin YL, Li D, Kim SW, Wu G: Amino acids and immune function. Br J Nutr 2007, 98:237-252

105. Donato J Jr, Pedrosa RG, Cruzat VF, Pires IS, Tirapegui J: Effects of leucine supplementation on the body composition and protein status of rats submitted to food restriction. Nutrition 2006, 22:520-527.

106. Frexes-Steed M, Lacy DB, Collins J, Abumrad NN: Role of leucine and other amino acids in regulating protein metabolism in vivo. Am J Physiol 1992, 262:E925-E935.

107. Bassit RA, Sawada LA, Bacurau RF, Navarro F, Martins E Jr, Santos RV, Caperuto EC, Rogeri P, Costa Rosa LF: Branched-chain amino acid supplementation and the immune response of long-distance athletes. Nutrition 2002, 18:376-379.

108. Blomstrand $E$, Saltin B: BCAA intake affects protein metabolism in muscle after but not during exercise in humans. Am J Physiol Endocrinol Metab 2001, 281:E365-E374.

109. Phillips SM: Dietary protein requirements and adaptive advantages in athletes. Br J Nutr 2012, 108(Suppl 2):S158-S167.

110. D'Antona G, Ragni M, Cardile A, Tedesco L, Dossena M, Bruttini F, Caliaro F, Corsetti G, Bottinelli R, Carruba MO, Valerio A, Nisoli E: Branched-chain amino acid supplementation promotes survival and supports cardiac and skeletal muscle mitochondrial biogenesis in middle-aged mice. Cell Metab 2010, 12:362-372.

111. Shimomura $Y$, Inaguma A, Watanabe S, Yamamoto $Y$, Muramatsu $Y$, Bajotto G, Sato J, Shimomura N, Kobayashi H, Mawatari K: Branched-chain amino acid supplementation before squat exercise and delayed-onset muscle soreness. Int J Sport Nutr Exerc Metab 2010, 20:236-244.

112. de Araujo JA, Falavigna G, Rogero MM, Pires ISO, Pedrosa RG, Castro IA, Donato J, Tirapegui J: Effect of chronic supplementation with branched-chain amino acids on the performance and hepatic and muscle glycogen content in trained rats. Life Sci 2006, 79:1343-1348.

113. Gulati P, Gaspers LD, Dann SG, Joaquin M, Nobukuni T, Natt F, Kozma SC, Thomas AP, Thomas G: Amino acids activate mTOR complex 1 via Ca2 +/CaM signaling to hVps34. Cell Metab 2008, 7:456-465.

114. Ra SG, Miyazaki T, Ishikura K, Nagayama H, Suzuki T, Maeda S, Ito M, Matsuzaki Y, Ohmori $\mathrm{H}$ : Additional effects of taurine on the benefits of BCAA intake for the delayed-onset muscle soreness and muscle damage induced by high-intensity eccentric exercise. Adv Exp Med Biol 2013, 776:179-187.

115. Newgard CB: Interplay between lipids and branched-chain amino acids in development of insulin resistance. Cell Metab 2012, 15:606-614.

116. Ranchordas MK, Burd NA, Godfrey RJ, Senchina DS, Stear SJ, Burke LM, Castell LM: A-Z of nutritional supplements: dietary supplements, sports nutrition foods and ergogenic aids for health and performance: Part 43. Br J Sports Med 2013, 47:399-400.

117. Marshall K: Therapeutic applications of whey protein. Altern Med Rev 2004, 9:136-156

118. Luhovyy BL, Akhavan $\mathrm{T}$, Anderson $\mathrm{GH}$ : Whey proteins in the regulation of food intake and satiety. J Am Coll Nutr 2007, 26:704S-712S.

119. Maughan RJ: Quality assurance issues in the use of dietary supplements, with special reference to protein supplements. J Nutr 2013, 143:1843S-1847S.

120. Hoppe C, Andersen GS, Jacobsen S, Mølgaard C, Friis H, Sangild PT, Michaelsen KF: The Use of Whey or Skimmed Milk Powder in Fortified Blended Foods for Vulnerable Groups. J Nutr 2008, 138:145S-161S 
121. Ha E, Zemel MB: Functional properties of whey, whey components, and essential amino acids : mechanisms underlying health benefits for active people (review). J Nutr Biochem 2003, 14:251-258.

122. Soares MJ, Murhadi LL, Kurpad AV, Chan She Ping-Delfos WL, Piers LS: Mechanistic roles for calcium and vitamin $D$ in the regulation of body weight. Obes Rev 2012, 13:592-605.

123. Gaudel C, Nongonierma AB, Maher S, Flynn S, Krause M, Murray BA, Kelly PM, Baird AW, FitzGerald RJ, Newsholme P: A whey protein hydrolysate promotes insulinotropic activity in a clonal pancreatic $\beta$-cell line and enhances glycemic function in ob/ob mice. J Nutr 2013, 143:1109-1114.

124. Josse AR, Atkinson SA, Tarnopolsky MA, Phillips SM: Increased consumption of dairy foods and protein during diet- and exercise-induced weight loss promotes fat mass loss and lean mass gain in overweight and obese premenopausal women. J Nutr 2011, 141:1626-1634.

125. Burd NA, Yang Y, Moore DR, Tang JE, Tarnopolsky MA, Phillips SM: Greater stimulation of myofibrillar protein synthesis with ingestion of whey protein isolate $\mathbf{v}$. micellar casein at rest and after resistance exercise in elderly men. Br J Nutr 2012, 108:958-962.

126. Tang JE, Moore DR, Kujbida GW, Tarnopolsky MA, Phillips SM: Ingestion of whey hydrolysate, casein, or soy protein isolate: effects on mixed muscle protein synthesis at rest and following resistance exercise in young men. J Appl Physiol 2009, 107:987-992.

127. Burke DG, Chilibeck PD, Davidson KS, Candow DG, Farthing J, Smith-Palmer T: The effect of whey protein supplementation with and without creatine monohydrate combined with resistance training on lean tissue mass and muscle strength. Int I Sport Nutr Exerc Metab 2001, 11:349-364.

128. Lands LC, Grey VL, Smountas AA: Effect of supplementation with a cysteine donor on muscular performance. J Appl Physiol 1999, 87:1381-1385.

129. Reidy PT, Walker DK, Dickinson JM, Gundermann DM, Drummond MJ, Timmerman KL, Fry CS, Borack MS, Cope MB, Mukherjea R, Jennings K, Volpi E, Rasmussen BB: Protein blend ingestion following resistance exercise promotes human muscle protein synthesis. J Nutr 2013, 143:410-416.

130. Hartman JW, Tang JE, Wilkinson SB, Tarnopolsky MA, Lawrence RL, Fullerton AV, Phillips SM: Consumption of fat-free fluid milk after resistance exercise promotes greater lean mass accretion than does consumption of soy or carbohydrate in young, novice, male weightlifters. Am J Clin Nutr 2007, 86:373-381.

131. Kinscherf R, Fischbach T, Mihm S, Roth S, Hohenhaus-Sievert E, Weiss C, Edler $L$, Bartsch P, Droge W: Effect of glutathione depletion and oral $\mathrm{N}$-acetyl-cysteine treatment on CD4+ and CD8+ cells. FASEB J 1994, 8:448-451.

doi:10.1186/s12970-014-0061-8

Cite this article as: Cruzat et al: Amino acid supplementation and impact on immune function in the context of exercise. Journal of the International Society of Sports Nutrition 2014 11:61.

\section{Submit your next manuscript to BioMed Central and take full advantage of:}

- Convenient online submission

- Thorough peer review

- No space constraints or color figure charges

- Immediate publication on acceptance

- Inclusion in PubMed, CAS, Scopus and Google Scholar

- Research which is freely available for redistribution

Submit your manuscript at www.biomedcentral.com/submit
C Biomed Central 